in serum from 11 out of 18 patients with primary hypothyroidism that blocked the increase in cyclic adenosine monophosphate stimulated by bovine thyroid stimulating hormone in cultured thyroid adenoma cells." Our findings may be of greater clinical relevance as whole serum, not just the IgG fraction, was examined and secretion of thyroid hormone by thyroid tissue was measured; this is the first report of a direct inhibitory effect on such secretion.

The clinical importance of this blocking effect found in vitro needs to be assessed further, but it is probably an important factor contributing to the pathogenesis of some cases of primary hypothyroidism.

This work was supported by the Medical Research Council and the scientific and research committee of Newcastle Health Authority.

Bovine thyroid stimulating hormone (Thytropar) was purchased from Armour Pharmaceutical, ${ }^{125}$ I triiodothyronine from Amersham International, Buckinghamshire, HEPES from Flow Laboratories, and bovine IgG from Sigma, London. All other chemicals were of analytical grade.

\section{References}

${ }^{1}$ Matsuura N, Yamada Y, Nohara Y, et al. Familial neonatal transient hypothyroidism due to maternal TSH-binding inhibitor immunoglobulins. N Engl f Med 1980;303:738-41.
${ }^{2}$ Endo K, Kasagi K, Konishi J, et al. Detection and properties of TSHbinding inhibitor immunoglobulins in patients with Graves' disease and Hashimoto's thyroiditis. F Clin Endocrinol Metab 1978;46:734-9.

${ }^{3}$ Atkinson S, Kendall-Taylor $P$. The stimulation of thyroid hormone secretion in vitro by thyroid stimulating antibodies. $\mathcal{F}$ Clin Endocrinol Metab 1981 ;53:1263-6.

- Wide L. Radioimmunoassays employing immunosorbents. Acta Endocrinol (Copenh) 1969;142, suppl:207-21.

s Shewring G, Smith BR. An improved radioreceptor assay for TSH receptor antibodies. Clin Endocrinol 1982;17:409-17.

${ }^{6}$ Humphries H, Dirmikis S, Munro DS. Comparison of human and porcine thyroid membranes for radioreceptor assay of bovine thyrotrophin and thyrotrophin-binding inhibiting immunoglobulins. F Endocrinol 1982; 93:371-80.

7 Biro J. Specific binding of thyroid-stimulating hormone by human serum globulins. F Endocrinol $1981 ; 88: 339-49$.

${ }^{8}$ Lazarus JH, John $\mathrm{R}$, Ginsberg J, et al. Transient neonatal hyperthyrotrophinaemia: a serum abnormality due to transplacentally acquired antibody to thyroid stimulating hormone. $B r \operatorname{Med} \mathcal{F} 1983 ; 286: 592-4$.

${ }^{9}$ Drexhage HA, Bottazzo GF, Bitensky L, Chayen J, Doniach D. Thyroid growth-blocking antibodies in primary myxoedema. Nature $1981 ; \mathbf{2 8 9}$ : 594-6.

${ }^{10}$ Yavin E, Yavin Z, Schneider MD, Kohn LD. Monoclonal antibodies to the thyrotrophin receptor: implications for receptor structure and the action of autoantibodies. Proc Natl Acad Sci USA 1981;78:3180-4.

$"$ Konishi J, Iida Y, Endo $\mathrm{K}$, et al. Inhibition of thyrotrophin-induced adenosine $3^{\prime} 5^{\prime}$-monophosphate increase by immunoglobulins from patients with primary myxedema. F Clin Endocrinol Metab 1983;57: 544-9.

(Accepted 23 February 1984)

\title{
IgA deficiency during treatment of infantile hypothyroidism with thyroxine
}

\author{
J SEAGER
}

\section{Abstract}

Serum IgA concentrations in five children with infantile hypothyroidism fell soon after the start of treatment with thyroxine. In one child the IgA concentration fell appreciably (to $<0.01 \mathrm{~g} / \mathrm{l}$ ) and remained reduced; in the four others it returned to normal. IgM and IgG concentrations were roughly normal throughout.

The deficiency in IgA concentrations may have been due to stimulation by thyroxine treatment of a $T$ cell suppressor system that, in the original hypothyroid state, was less than normally active.

\section{Introduction}

Selective IgA deficiency occurs in about one in 500 of the general population and is sometimes familial. It is the commonest immunodeficiency state, and known causes include treatment with various drugs, including phenytoin, penicillamine, sodium aurothiomalate, and sulphasalazine. ${ }^{1}$ I report on five children with hypothyroidism in whom IgA concentrations fell during the first few months of treatment with thyroxine.

Department of Paediatrics, Arrowe Park Hospital, Upton, Wirral, Merseyside

J SEAGER, MD, MRCP, consultant paediatrician

\section{Patients and methods}

Five girls aged from 11 months to 4 years 9 months were diagnosed as having infantile hypothyroidism on the basis of clinical findings together with low serum thyroxine concentrations and raised thyroid stimulating hormone concentrations in the blood. Serum immunoglobulin concentrations were measured by single radial immunodiffusion (Partigen plates, Hoechst). Blood was taken from each child at the time of diagnosis and again whenever thyroid function tests were monitored during treatment with thyroxine sodium.

\section{Results}

In all five girls serum IgA concentrations fell after treatment with thyroxine was started (figure). In four of them IgA concentrations fell below the range of normal for healthy British children. ${ }^{2}$ In one child the serum IgA concentration fell to less than $0.01 \mathrm{~g} / 1$ and remained reduced. IgA concentrations returned to normal in the other four and then increased with age in the usual way. Concentrations of IgG and IgM generally fluctuated within the normal range during treatment; one child, however, had a marginally low IgG concentration at seven months, and three children developed marginally raised IgM concentrations between 18 months and three years after the start of treatment.

The child who developed long lasting IgA deficiency subsequently did not show any evidence of recurrent infection or allergic disease. Four years after the start of treatment with thyroxine her serum gave a negative result when tested for thyroid microsomal and colloid antibodies.

\section{Discussion}

Physical and intellectual development are delayed in children with infantile hypothyroidism. The development of their 
immune systems and particularly of IgA concentrations, which normally rise with age, might also be expected to be delayed. Before treatment, however, four of the five children had IgA concentrations that lay within the normal range.

The early fall in IgA concentration after the start of treatment with thyroxine was unexpected. There is no reason to suppose that a return to normal metabolism will lead to a redistribution

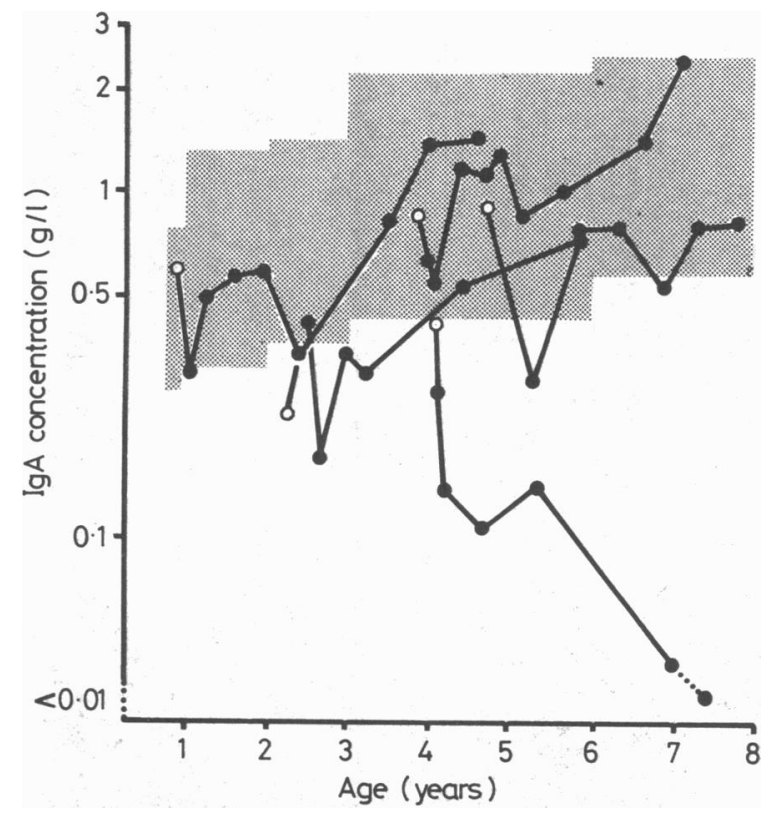

Immunoglobulin concentrations in five children before (O) and during ( $-O)$ treatment with thyroxine. The shaded area gives mean (2 SD) concentrations for healthy British children. ${ }^{2}$ of IgA within the body. The fall in IgA concentration is unlikely to have been due to a non-specific increase in catabolism as IgA has a shorter half life than IgG or IgM and should therefore be the least affected class of immunoglobulins. In selective IgA deficiency induced by phenytoin, ${ }^{3}$ and in many other immunoglobulin deficiencies, normal proportions of $\mathbf{B}$ cells bearing IgA have been found in the blood. Defective production of immunoglobulins has apparently been due to the failure of terminal maturation. In common variable hypogammaglobulinaemia Waldman et al showed that this failure may be due to the presence of suppressor $T$ lymphocytes in the circulation. ${ }^{4}$ This seems to be borne out by the recently described case of a patient with antibody deficiency induced by drugs who was shown to have abnormal suppressor $\mathrm{T}$ cell activity. ${ }^{5}$ The IgA deficiency seen here in children receiving hormone replacement treatment might have been due to stimulation of a $T$ cell suppressor system that, in the original hypothyroid state, was less than normally active.

I thank Dr T B Hales and the department of chemical pathology for immunoglobulin measurements and Miss L Blair for secretarial help.

\section{References \\ ${ }^{1}$ Delamere JP, Farr M, Grindulis KA. Sulphasalazine induced selective IgA deficiency in rheumatoid arthritis. Br Med $71983 ; 286: 1547-8$. \\ ${ }^{2}$ Hobbs JR. Simplified radial immunodiffusion. Association of clinical pathologists broadsheet 1970:No 68 (appendix). \\ ${ }^{3}$ Seager J, Jamison DL, Wilson J, Hayward AR, Soothill JF. IgA deficiency, epilepsy and phenytoin treatment. Lancet $1975 ;$ ii :632-5. \\ 4 Waldman TA, Durm M, Broder S, Blackman M, Blease RM, Strober W. Role of suppressor $T$ cells in pathogenesis of common variable hypo- gammaglobulinaemia. Lancet 1974 ;ii:609-13. \\ ${ }^{5}$ Dosch $\mathrm{H}-\mathrm{M}$, Jason J, Gelfand EW. Transient antibody deficiency and abnormal T suppressor cells induced by phenytoin. $N$ Englf $M e d 1982$; 306:406-9.}

(Accepted 1 March 1984)

\title{
Detection of hepatitis B virus DNA in mononuclear blood cells
}

\author{
P PONTISSO, M C POON, P TIOLLAIS, C BRECHOT
}

\begin{abstract}
The Southern transfer hybridisation technique was used to test mononuclear blood cells for hepatitis B virus DNA. Viral DNA sequences were detected in mononuclear cells of 10 out of 16 patients with hepatitis $B$ virus infection and in none of 21 normal controls. Blood contamination was excluded by the absence of hepatitis $B$ virus DNA in the corresponding serum samples in all cases.
\end{abstract}

\footnotetext{
Unité de Recombinaison et Expression Genetique (INSERM U 163, CNRS LA 271), Institut Pasteur, 75724 Paris Cedex 15, France P PONTISSO, MD

P TIOLLAIS, $M$ D

C BRECHOT, MD
}

University of Calgary and Foothills Hospital, Calgary, Alberta, Canada T2N4N1

M C POON, MD

Correspondence to: Dr C Brechot.
Free monomeric hepatitis $B$ virus DNA was found in three patients positive for hepatitis Be antigen (HBeAg) and one positive for anti-HBe, and integrated hepatitis $B$ virus DNA was present in four patients positive for anti-HBe. In two other patients the small size of the samples did not allow a distinction between free and integrated viral DNA. The state of the virus in the mononuclear cells seemed to correlate with the $\mathrm{HBeAg}$ or anti-HBe state, as has been noted in the liver.

These results indicate that hepatitis $B$ virus may infect mononuclear blood cells, thereby expanding the tissue specificity of this agent beyond the liver, as has been reported for pancreatic, kidney, and skin tissue. They also suggest that hepatitis $B$ virus infection of mononuclear cells might be related to immunological abnormalities observed in carriers of the virus.

\section{Introduction}

Immunological abnormalities are often present in patients infected with hepatitis $B$ virus and may be responsible for 